\title{
"Sou um homossexual não praticante": entrevista com Marcelino Freire
}

Por Christian Grünnagel ${ }^{1}$ e Doris Wieser ${ }^{2}$

\section{O que significa ser homem ou ser mulher para você?}

A masculinidade e, sobretudo, para mim, que nasci no Nordeste do Brasil, no sertão de Pernambuco, exige muito do homem. A figura do homem é aquela do homem forte, do homem que trabalha no campo, é daquele homem que ajuda a família, que trabalha capinando, que sobe em cavalo, enfrenta matas muito fechadas. E eu nasci exatamente nessa região; sou caçula de uma família de nove filhos: oito homens, uma mulher. Então essa exigência do esforço físico existiu desde quando eu nasci. Só que eu não tinha essa resposta para dar à minha família. Eu sempre fui muito preguiçoso, muito mais feminino do que masculino no sentido de que eu era mais para o trabalho frágil; eu não tinha força alguma para cumprir todas essas exigências masculinas, extremamente heterossexuais. Eu era uma figura que, em casa, fazia tudo o que meus sete irmãos não faziam, por exemplo, escrever as cartas da casa, porque eu já gostava de ler e escrever. Era eu quem lia a Bíblia para minha mãe, eu quem lia as bulas de remédio. Não me mandassem fazer trabalho pesado! Meu trabalho era mais intelectual. Nesse sentido, eu era muito respeitado por esse ofício, mas já sabia que eu estava muito mais para uma posição feminina, para uma sensibilidade e emotividade mais aguçadas. Então, eu ia muito contra a predominância masculina, sobretudo nesse sertão. Aos nove anos de idade eu pedi para minha mãe para eu fazer teatro na escola onde eu estudava, porque eu achava muito interessante o teatro, já tinha ouvido falar de teatro. E eu fiz teatro dos nove aos dezenove anos, e mais uma vez isso era ligado mais ou a uma coisa de mulher ou de homossexual. Eu percebia que em casa eu era uma figura que estava mais ligada a esses apelos mais sensíveis do que ao cara que tinha toda a predominância masculina. Então, para

\footnotetext{
${ }^{1}$ Doutor em letras românicas e professor do Instituto de Filologia Românica da Universidade de Giessen, Giessen, Alemanha. E-mail: christian.gruennagel@ romanistik.uni-giessen.de

2 Doutora em literatura ibero-americana e professora do Instituto de Filologia Românica da Universidade de Göttingen, Göttingen, Alemanha. Atualmente bolsista de pós-doutorado da Fundação Alexander von Humboldt na Universidade de Lisboa. E-mail: doris.wieser@phil.unigoettingen.de
} 
mim, ser masculino no Brasil, ser homem no Brasil - sobretudo no Nordeste do País - era estar ligado mais a essa alma feminina. Eu não sei se eu te respondi, mas a ideia que eu tenho é muito ligada às escolhas que eu fiz e que meu corpo e minha alma pediam.

E como foi a relação com os seus irmãos homens? Você foi um outsider dentro do grupo dos seus irmãos ou sempre houve uma boa relação de amizade entre todos vocês?

A gente se respeitava muito. Eu me lembro de que na minha casa eu comecei a ser respeitado muito por essa função que eu exercia e que nenhum outro fazia. Nenhum outro lia. Eu fui o primeiro leitor da minha família e creio que eu continuo sendo o único. Eu era aquele menino que estava lendo enquanto meus irmãos jogavam bola ou aprendiam a dirigir. Minha mãe abria a porta do meu quarto e perguntava se eu estava doente, porque eu era um menino que ficava o tempo inteiro com os livros. Eu nunca fui um menino saudável no sentido dessa saúde que se espera de um menino sertanejo, nordestino, de estar brincando, jogando bola, suando. Eu, no entanto, era uma figura mais recolhida. Quando viram que esse recolhimento fazia de mim um ótimo leitor, um ótimo escritor de cartas, eles começaram a me respeitar por isso. Eu até tenho em minha memória muita gratidão nesse sentido, porque foi a primeira vez que eu senti ser respeitado pelas escolhas que eu fiz. Eu era respeitado naquela função que eu desempenhava. Eu era respeitado como escritor, como leitor, por fazer frases muito bonitas quando escrevia cartas, por ler bem a Bíblia para minha mãe. Quando o padre do bairro ia à casa das pessoas para fazer uma missa, minha mãe me convocava imediatamente para ler um trecho da Bíblia. Eu não sei se aqui tem isso, mas no Nordeste existe a cultura de fazer uma espécie de peregrinação para uma santa; a santa fica por um mês na casa de uma pessoa. E, quando vão pegar essa santa para levar para outra casa, o padre vai lá para rezar uma missa. Então, toda vez que o padre ia lá em casa, eu era designado para ler a Bíblia. Isso com dez, onze, doze anos, então todos me respeitavam muito. "Nossa, que menino que lê bem, olha como ele lê bonito". Então a relação era muito boa. Eu escolhi fazer teatro muito novo e essa era uma decisão estranha para eles, mas quando havia as temporadas das peças a família toda estava lá. A família gostava: “Ah, meu filho está fazendo alguma coisa. Ele está sendo respeitado na escola. Os diretores vão lá 
assistir ao que ele faz". A relação foi normalíssima. Havia algum atrito com um ou dois irmãos que não entendiam o porquê de eu não ir à feira com a minha mãe, o porquê de eu ser protegido no sentido de não fazer um trabalho pesado. E então eles implicavam um pouco com isso: "Ah, só porque ele é escritor, só porque ele é doente". Porque eu também fui um rapaz muito doente; ainda muito novo, eu descobri que tinha um sopro no coração e tive que me tratar. Eu tinha anemia, era caçula, então eu era um pouco paparicado, o que gerava algum atrito.

\section{Que importância tem hoje em dia o machismo no Nordeste?}

Em Recife há muito machismo, assim como no Nordeste como um todo. Eu não nasci em Recife, nasci em uma cidade chamada Sertânia, que fica a 380 quilômetros do Recife. Minha família é de retirantes, saiu toda de Sertânia. Minha mãe saiu com nove filhos, porque não tinha trabalho e fomos para Paulo Afonso, na Bahia. Depois de Paulo Afonso todos nós fomos morar no Recife, capital de Pernambuco, onde morei dos 8 aos 24 anos de idade. Recife hoje ainda é a cidade com o maior índice de violência contra a mulher. $O$ Recife concentra muito a vinda de sertanejos, de retirantes vindos de vários lugares de Pernambuco e também de todo o Nordeste. Ele é, digamos, uma cidade muito central no Nordeste. Há uma crença de que no Recife você tem mais oportunidade do que em Fortaleza e mais tranquilidade do que em Salvador. Então o Recife concentra o maior número de imigrantes de regiões rurais. Daí, o machismo já vem de longe. Já vem com esses retirantes, digamos.

\section{Como o Severino, de João Cabral.}

Isso. Porque é para onde ele vai, para o Recife, em Morte e vida severina. ${ }^{3}$ E essas pessoas que vêm de regiões muito distantes são muito machistas, não têm o pensamento da metrópole. Por isso, por qualquer coisa que fira a dignidade deles, qualquer olhar diferente para a mulher, a namorada que foi dançar com outro, eles puxam a peixeira, a arma e matam por bobagem. É umas das cidades mais violentas em relação à

\footnotetext{
${ }^{3}$ Poema dramático do escritor pernambucano João Cabral de Melo Neto, publicado em 1955. Relata o percurso de um retirante que vai caminhando do sertão ao litoral em busca de melhores condições de vida, acabando a viagem em Recife.
} 
mulher, porque há muitos assassinatos nesse sentido, por nada. E também é a cidade que mais tem ataques homofóbicos, em função dessa concentração de pessoas que ainda estão vivendo em um comportamento muito conservador. Com a ideia de que a mulher tem que servir o homem, tem que se casar e cozinhar bem, tem que renunciar à sua vida profissional para cuidar dos filhos... isso é recorrente. A geração da minha mãe é assim. A minha irmã cuidou dos filhos a vida toda. E ainda hoje eu vejo que meus sobrinhos - são mais de vinte - casam muito cedo, já têm filhos e cultuam muito essa coisa da família, em que a mulher sempre está pronta para servir.

Você diria que na classe média, em uma metrópole como São Paulo ou Rio de Janeiro, há menos machismo e menos homofobia?

Comparativamente é menos, mas, se você for para a periferia de São Paulo, você tem ataques maiores, violência maior contra a mulher. A periferia de São Paulo é feita, em sua maioria, de nordestinos. São Paulo é a cidade mais nordestina do Brasil.

\section{É uma migração interna... e levam a cultura deles para lá.}

E, por condições financeiras precárias, eles vão morar na periferia de São Paulo, onde há o mesmo problema: mata-se com facilidade, qualquer discussão vira morte, a questão da mulher e do serviço doméstico também. Se você for analisar a periferia de São Paulo, você vai encontrar o mesmo problema existente no Nordeste. Mas tais problemas você encontra no Brasil todo; se você for para o Amazonas, você vai encontrar o mesmo problema. Quando mais se tem uma educação fragilizada, mais se tem esse conceito menos aberto para o comportamento, para os relacionamentos.

Você já falou um pouco da homofobia, mas talvez poderia falar um pouco mais sobre o estado atual dos gays no Brasil, tanto homens quanto mulheres. Quão difícil é viver a vida hoje em dia com a homofobia? Há espaços abertos para eles?

Não sei se vocês sabem, mas eu sou homossexual. E eu costumo dizer que eu sou um homossexual não praticante. 
Eu li essa frase numa das suas entrevistas e fiquei me perguntando o que queria dizer com isso.

Eu digo que eu sou homossexual não praticante pelo seguinte: eu tenho muita fé, sou devoto. Aí eu faço uma "brincadeira" de que eu sou homossexual não praticante porque eu não preciso ficar praticando o tempo inteiro para dizer que tenho essa fé. É evidente que eu faço uma brincadeira em relação à exigência de que todo homossexual pratique a militância. O tempo inteiro você está sendo solicitado para participar de passeatas, de comissões... Quando um católico é não praticante, ele não precisa ir à igreja para dizer que acredita em Deus. Então, eu digo que frequento muito pouco a militância homossexual, os guetos. Evidentemente convivo, mas frequento muito pouco. É que me parece que, em algum momento, para ser um homossexual legítimo, tem-se que ser um homossexual que está o tempo inteiro militando. E não é bem assim... Mas isso é só uma frase minha, de efeito. Sempre que posso, entro na luta, sim, grito, esperneio. E pratico, sim, minha homossexualidade. Não sou casto. Abertos esses parênteses, a questão da homossexualidade no Brasil tem avançado. Muitas leis civis têm sido aprovadas a favor do direito aos casais homossexuais. Isso tem sido bastante discutido e tem, o país, se mobilizado muito nesse sentido. É claro que vocês devem estar sabendo de um deputado no Brasil que é presidente da Comissão dos Direitos Humanos no Governo e que é homofóbico. ${ }^{4} \mathrm{E}$ a gente caiu de pau; todo mundo se mobilizou para combater isso, para dizer o absurdo que é um homem desse estar presidindo essa Comissão. É um homofóbico declarado, um evangélico, que prega a cura gay e o tratamento da homossexualidade. O Brasil é muito grande, é imenso, e, se esse deputado que defende a cura gay, que defende a perseguição aos homossexuais e atrapalha o crescimento dos direitos dos homossexuais dentro do Congresso, tem $10 \%$ da população do lado dele, ele vira o que ele quiser. Ele faz isso porque sabe que vai convencer $10 \%$ de uma população que pensa igual a ele; ele defende isso porque tem quem o apoia. E com isso ele vai fazendo a sua plataforma e chegando a cargos políticos que quiser. O Brasil caminha dez passos para a frente, cinco passos para trás. Aconteceram recentemente muitos ataques homofóbicos em São Paulo e o tempo inteiro a gente tem que continuar brigando por isso. E repito: quando brinco dizendo que eu sou um homossexual não

\footnotetext{
${ }^{4}$ Marco Feliciano.
} 
praticante, é evidente que é uma piada, mas sempre que é necessário se mobilizar eu me mobilizo. Eu estive em um programa de televisão, no qual me mobilizei contra isso, onde li um texto meu. Textos que são muito difundidos no grupo homossexual e sempre são vistos como referência dessa luta. ${ }^{5}$ É claro que eu não deixo de lutar e praticar. Mas a situação é assim: se tem caminhado, mas é um país imenso. E volto a dizer: se $10 \%$ da população é preconceituosa, se cria uma resistência ao assunto, esses $10 \%$ podem dificultar muito as coisas, as coisas ficam mais difíceis de mudar tão rapidamente.

Você acha que a masculinidade homossexual se difere da masculinidade heterossexual?

A masculinidade de um homossexual está mais para "ser humano", "ser mais humano"... Nada exacerbado, que precise provar o tempo inteiro o quanto é macho. A masculinidade homossexual não é macha. É machucada. Não tem vergonha de ser "sensível". A masculinidade heterossexual, parece que, o tempo inteiro, tem de demonstrar força, testosterona.

Fala-se muito de uma identidade homossexual. É errada essa ideia? Há uma identidade especial ou há apenas algo humano e pronto?

Eu vou te dizer muito sinceramente: eu nunca me senti masculino. Assim como nunca me senti feminino. Eu me sinto muito "humano". Eu não vejo isso como categorias que fiquem isoladas, respeitando a padrões de masculinidade, de feminilidade. Eu me sinto muito mais entregue às possibilidades todas. Eu não sei se um cara que tem a masculinidade como definição muito própria do seu ser não está sendo colocado ali de forma muito categorizada. Eu me comporto de forma muito natural, muito mais livre para a compreensão do mundo, com um olhar muito mais aberto. Eu vejo o ser humano como humano e não dentro dessa categoria de ser masculino ou feminino. Nesse sentido, eu acho que o masculino homossexual, ratificando a resposta anterior, é um masculino que não está para o homem, mas, sim, para o humano.

${ }^{5}$ Veja-se, sobretudo: FREIRE, Marcelino (2010). Amar é crime. São Paulo: Edith. 
Eu pergunto isso porque uma socióloga australiana, R. W. Connell, fala de vários projetos de masculinidade, ou seja, masculinidades. Ela distingue, por exemplo, uma masculinidade economicamente marginalizada de uma masculinidade subordinada (homossexual) e de uma masculinidade hegemônica (heterossexual). ${ }^{6}$ Não sei se no Brasil encontram-se também diferentes "projetos" de masculinidade.

$\mathrm{Eu}$ acho particularmente que a predominância da masculinidade no Brasil é dessa masculinidade hétero. O Brasil é um país machista, que tem que avançar muito ainda nessas coisas - e o masculino é o masculino. Se o masculino recebe uma outra categoria próxima - um masculino "isso" - já não é mais masculino. Ou você é homem ou você não é homem. O masculino no Brasil tem essa definição muito mais "hétero", como um grupo homogêneo, de postura arrogante. Repetindo: é um país muito grande e, para termos o mínimo de representatividade nisso, ainda vai demorar.

Falamos até agora muito dos homens. O que se passa com as mulheres homossexuais neste movimento político, nas manifestações, no CSD em São Paulo? Têm algum peso lá ou é um movimento liderado pelos gays homens?

Pelos gays homens. Para você ter uma ideia, a Passeata da Diversidade Sexual é imensa, acontece no domingo; e, em um sábado antes, acontece, separadamente, a passeata das lésbicas.

\section{É separado? Na Europa não é separado...}

É separado. No domingo todos se juntam, é claro. Mas no Brasil se faz, antes da parada gay, um encontro só para as lésbicas, e o número não é tão grande, o público é mais reduzido. Parece-me - e aí eu posso estar muito enganado, é o que eu ouço os homens falarem, até mesmo os homossexuais - que ser lésbica é muito mais fácil, porque mulher com mulher, estar de mão dada, cumprimentando uma a outra, ser mais íntimo de uma mulher, dormir e ir ao banheiro junto, é muito mais natural, é muito mais aceitável. O carinho entre mulheres é muito mais comum.

\footnotetext{
${ }^{6}$ Para mais detalhes sobre o enfoque teórico de Connell, veja-se o texto introdutório deste dossiê.
} 
Mas falar com os pais: "Essa é minha namorada, vou morar com ela", não é tão fácil assim, eu acho.

Não é fácil, mas me parece que as lésbicas não se organizam tanto porque elas já estão naturalmente inseridas e não sofrem a mesma perseguição sofrida pelos homossexuais masculinos. Diz, a maioria: "Não transformamos o nosso corpo, não chegamos aos extremos para ter a coisa do transexual, da travesti...". Quando você fala para o cara mais machista no Brasil: "Ah, e se aquelas duas mulheres estiverem vivendo juntas e forem namoradas...", ele, com certeza, dirá: "Ah, mas aí eu como as duas". Outra coisa: ver dois homens se beijando? Jamais! Agora, ver duas mulheres, o cara, até o mais machão, vai falar, "ah, é bonito".

\section{Isso também é machismo.}

É claro. É menor a mobilização das mulheres, mas se mobilizam igualmente. A gente brinca até que a passeata é "GLBTUVXZ". A mobilização é geral. O que me preocupou uma época - o que eu falei inclusive em jornais - é que parecia que a passeata acontecia naquele dia, virava uma festa, um carnaval, como tudo no Brasil, e depois daquele dia continuava tudo a mesma coisa: o homossexual voltava para casa e era espancado, o outro tinha os direitos caçados e não respeitados, em função do companheiro que ele tinha há muito tempo. Até que, de uns tempos para cá, tem-se acordado de fazer uma mobilização que, de fato, mude as leis. Ou seja, se eles propagavam dois milhões, cinco milhões de pessoas na rua para "desfilar" pelos direitos dos homossexuais, isso deveria, sim, se reverter em assinaturas, que exigissem do governo as mudanças que têm de ser feitas. Quem é uma lutadora ferrenha disso no Brasil é a ministra da Cultura Marta Suplicy,7 que estava aqui hoje tomando um café com a gente. E ela é uma das que lutam muito pelos direitos dos homossexuais. É muito querida pela classe.

E você acha que a masculinidade e a feminilidade são coisas naturais ou aprendidas, construídas pela sociedade e pela cultura? A discussão de

\footnotetext{
${ }^{7}$ Marta Suplicy, formada em psicologia, trabalhou como apresentadora do programa TV Mulher (Rede Globo) nos anos 1980, fundou a ONG Grupo de Trabalho e Pesquisa em Orientação Sexual (GTPOS), que capacita profissionais de saúde e educação na área de orientação sexual e prevenção da AIDS, foi deputada federal pelo PT de 1995 a 1998, prefeita de São Paulo de 2000 a 2004, ministra da Cultura de 2012 a 2014 e hoje é senadora.
} 
sempre nos estudos de gênero é se há uma base na natureza ou não. Qual é a sua opinião?

Quando eu comecei a perceber que minha inclinação não era heterossexual, imediatamente também percebi que eu era não era visto como "afeminado". Meus trejeitos eram mais "controlados", digamos. Não que eu censurasse os meus gestos. Mas eu era assim. Até hoje, muita gente pensa que eu não sou gay. De qualquer forma, eu nunca deixei de fazer as coisas que eu tinha que fazer: teatro; eu me lembro de levar meus amigos homossexuais lá para casa. Nunca censurei isso. Meus pais não entendiam muito o que eu estava fazendo com esses amigos que eram tão diferentes, "afeminados", digamos. Eles iam lá em casa, naturalmente, e eu sempre pensei que eu era quem tinha que educar meus pais para que eles enxergassem que existiam pessoas fora desse padrão "claramente masculino". Em resumo: eu nunca bloquei essa minha inclinação. Se eu fosse mais explicitamente gay, eu seria mais explicitamente gay. E lutaria, dentro de casa, por esse direito. Tem alguns homossexuais que chegam a se casar e, no entanto, são homossexuais. Eu nunca faria isso. Eu sempre me senti livre. Do jeito que eu sou.

Quer dizer que você resistiu a esse ambiente muito masculino, com oito irmãos?

Resisti muito a esse ambiente. Tem algo que é imposto pelo meio e tem algo que é imposto pelo corpo. Um exemplo são pessoas que nascem, digamos, no "corpo trocado" e que, por mais que cheguem moldados para aquele outro corpo, não conseguem. Eu trazia comigo a minha homossexualidade, tranquilamente e, para mim, era muito natural que eu mostrasse essas diferenças em casa e fora dela e educasse a minha família nesse sentido. Eu acho que há uma incidência forte dessa vontade de afirmar o que é masculino e feminino; mas existe uma outra coisa que já nasce com a gente e que vai se afirmando com o tempo também. Vou dar outro exemplo, eu não sei se tem a ver, mas estou raciocinando agora porque são perguntas muito difíceis essas que vocês fazem... Na escola, ambiente de garotos, de homofóbicos, há uma divisão muito clara entre menino e menina, muito bullying se se é frágil etc. A masculinidade à qual eu era submetido em casa era a mesma da escola. Na aula de educação física, de jogar bola, eu era horrível; se fosse para brigar eu apanhava; eu era uma mocinha. No entanto, eu exercia 
meu poder, em meio àquele ambiente desfavorável, que exigia de mim forças que eu não tinha; eu era forte na escrita, na palavra. Eu tinha notas excelentes e, se os meninos que dependiam de mim para passar de ano, viessem com onda para cima de mim, querendo me oprimir, querendo fazer bullying, não passavam na prova porque eu não dava cola para eles. Então, era uma coisa que não estava explicitamente combinada, mas eles sabiam disso. Eu acho que, por mais frágil que eu pudesse parecer em todos esses ambientes, eu era o mais forte de todos eles, porque eles acreditavam que você vale muito mais por uma força física e bruta e eu, do meu jeito, natural, dizia que não, que a força é da alma, daquilo que você faz e quer fazer da sua vida.

Nos seus contos há narradores e narradoras heterossexuais, narradores e narradoras homossexuais, personagens de todo tipo. Como é para você criar personagens de outros gêneros, por exemplo, a mãe lésbica que aparece no conto "Minha flor". Você trabalha de maneira diferente dependendo do gênero e da orientação sexual do personagem?

Eu nunca tenho uma história para contar. Eu não sei que história eu vou contar. Eu sempre tenho uma primeira frase, que eu ouço na rua ou que eu guardei na memória. Quando vou articulando essa primeira frase, vou descobrindo se o personagem é homossexual, se é heterossexual, se é uma puta, se é uma travesti, se é um padre. Em muitos desses contos, eu me deparo e digo "Aaah, esse é um padre! Nossa, esse aqui é um velho!". Eu vou investigando aquilo que aquelas palavras vão me dando e vou descobrindo o gênero do personagem. Já que você falou de "Minha flor", o livro BaléRalé é um livro no qual a temática homossexual aparece em praticamente todos os contos, desde a capa. Todos os meus livros têm contos ligados a essa temática. Até mesmo no primeiro conto desse livro - "Homo erectus", que fala sobre múmias, civilizações perdidas - já temos a temática homossexual como pano de fundo. Lendo um livro sobre civilizações antigas, certa vez, eu vi uma foto de duas múmias abraçadas, dois homens em posição de balé - por isso o nome do livro - e esse casal se tornou ícone na Holanda, sendo considerado "o casal gay mais antigo da Holanda". Eu vi que aquela imagem tinha tudo a ver com meu livro e fui atrás do museu para pedir permissão para usá-la. Fazendo o livro, eu notei que faltava um conto

\footnotetext{
${ }^{8}$ Em FREIRE, Marcelino (2003). BaléRalé. São Paulo: Ateliê.
} 
no qual a lésbica fosse a narradora. Quando eu encontro um tema para meu livro, busco também fazer contos específicos para ele. Aí foi quando eu escrevi o "Minha flor". BaléRalé é principalmente um livro sobre o preconceito. Fala, por exemplo, da história de um menino que resolveu fazer balé, que escolheu a arte em vez de trabalhar com os irmãos, de usar qualquer esforço físico. Tem muito da minha própria história na história desse menino. $\mathrm{O}$ fato de ele fazer balé não quer dizer que ele seja gay, mas há muito preconceito dos outros nesse sentido. Dessa mesma forma, há um conto chamado "A sagração da primavera", que é a história de uma mulher que se apaixona por um bailarino e sofre com o preconceito dos amigos que dizem que ele é gay, e não é verdade. No livro também há um conto "macho", de um sertanejo que se veste de maracatu para desfilar, que saía às ruas vestido de guerreiro, brilhando, "travestido" de força, dança, leveza, tradição. Enfim. O livro é repleto dessa discussão. Mas eu vou descobrindo o gênero, o sexo de cada um dos personagens a partir do momento em que vou escrevendo. $\mathrm{Na}$ verdade, meu gênero é a palavra, e é a palavra quem sempre diz para mim quem é velho, quem é puta, quem é menino, menina...

Esse livro de contos foi publicado na coleção LêProsa mas eu me pergunto se realmente é "prosaico". Tenho a impressão de que, sim, poderia ser prosa, mas talvez também um poema em prosa. Você vê alguma diferença entre um conto, um microconto e um poema em prosa?

Com relação ao que falávamos sobre gênero, eu quebro exatamente essas fronteiras de gênero. Por exemplo, no livro Contos negreiros, ${ }^{9}$ eu abro o livro com uma espécie de oração, de lamento nordestino. Eu nunca chamo os meus contos como tal, aqui eu chamo de "cantos", aqui eu chamo de "improvisos". Improvisos podem ser de dança, de música, como é o caso dos repentistas no Nordeste do Brasil. Portanto, eu nunca chamo meus contos de "contos", eu sempre tenho a necessidade de chamá-los de algo além disso, algo que tenha a ver com música, com o fato de eu ser nordestino, de escrever coisas que são muito rimadas, cordelizadas. Eu quebro todas essas fronteiras para me sentir mais livre. Quem tem que categorizar o que eu faço são os críticos. Quando eu estava escrevendo Rasif: mar que arrebenta, ${ }^{10}$ eu tive que fazer uma

\footnotetext{
${ }^{9}$ FREIRE, Marcelino (2005). Contos negreiros. Rio de Janeiro: Record.

${ }^{10}$ FREIRE, Marcelino (2008). Rasif: mar que arrebenta. São Paulo: Edith.
} 
oração para Iemanjá antes mesmo de falar de mar, como se tivesse pedindo permissão para adentrar esse tema e esse canto tão dela, da nossa Rainha do Mar. Meus textos são também muito ligados ao teatro, são muito teatrais e são muito encenados no Brasil. Também há textos meus que têm rimas invisíveis. Em alguns casos, você sabe onde a rima está; em outros momentos, os sons rimam mais internamente, formando uma fala só. Por isso, minha literatura costuma ser muito difícil para a tradução. Porque ela é uma canção, na verdade.

Talvez você pudesse falar um pouco mais da relação entre a literatura oral no Nordeste, quer dizer, a literatura de cordel, a improvisação, e essa vontade de fazer um texto sonoro, ideal para ser lido em voz alta. Você diria que a sua literatura está nessa tradição nordestina?

Eu escrevo em voz alta, de tal forma que o texto possa ser lido em voz alta. Meu texto só me convence quando eu consigo rezar os meus contos. Ou seja, quando eu termino um conto, eu o leio bem rápido - como se estivesse rezando - para poder ver como está o ritmo daquele conto. Ele tem que me convencer como se fosse essa ladainha, essa fala muito presente no universo nordestino. Se há algum problema nessa leitura, se algum som ficou vazio, quer dizer que alguma coisa no som não está batendo, tenho de mudar uma palavra, diminuir uma frase, para caber nesse "mantra". Quando os leitores terminam de ler, eles vêm sempre me dizer que ficaram com o som dos meus textos dentro da mente, como se houvesse uma ladainha, uma música saindo daí... É porque é isso. Meu texto é improviso, cantoria, vexame sonoro, reza para os ouvidos.

Você falou que no Brasil há muitas encenações dos seus contos. Como isso acontece?

Eu escrevo pensando em teatro. Fiz teatro desde muito pequeno. Gosto dessa palavra falada, passada para o outro. Há muitos diálogos e muitos monólogos meus em meus contos. Personagens falando pelos cotovelos. Um dos contos meus que mais foram encenados é o "Da paz"11. É um conto falado, gritado, doído. E eu pensei no corpo daquela mulher quando estava escrevendo. E no grito daquela mulher que perdeu o

${ }^{11}$ Publicado em Rasif: mar que arrebenta. 
filho. Meus contos têm que dizer alguma coisa. E o teatro é perfeito para isso. O teatro é a força da palavra tomando corpo, gesto, alma.

\section{Quer dizer que não é só a forma, mas também o conteúdo, a semântica da palavra?}

Sim. Nisso eu fui muito influenciado por minha mãe sertaneja. Ela falava muito. Minha mãe, quando estava muito feliz, cantava Luiz Gonzaga $^{12}$ na cozinha. Quando ela estava muito preocupada, batia panela. Assim, meus personagens têm essa harmonia, esse pacto com a fala da minha mãe; meus personagens, todos, falam muito, se mexem, se articulam, batem panela, o tempo inteiro fazem essa "ladainha" uma fala que parece que não vai acabar nunca. Vou mostrar, ler para vocês um conto. Observem a questão das rimas externas e internas:

Beijar na boca outro homem? Na língua? Essa depravação? para todo mundo saber? O quê? Não. Meu tempo era outro tempo. Beijava-se escondidinho outro homem. Assim, no Joaquim. Ninguém saía passeando com o namorado, para cima e para baixo, para cima e para baixo. Era tudo muito mais romântico. No meu tempo. A gente ia para boate americana, ia ver cinema aqui no centro. Se tinha sacanagem, era só para gente. Viado caçava ouvindo grito de Tarzã. Filme mudo, baixinho. Preto no branco. Ia muito nordestino. De manhã, no banco do parque, uma masturbação. A gente sabia usar a mão. E não tinha medo de ladrão, assalto de relógio. Ninguém responde mais que horas são. $\mathrm{O}$ mundo diferente. Você liga a televisão, aquele Carnaval. Febre de silicone, não. Não entendo. Apresentadora perguntando: "Qual o tamanho do seu pau?". Uma esculhambação. Bunda em banca de jornal. Você viu quem saiu nu? O jogador do Cruzeiro do Sul. ${ }^{13}$

\section{Nesse caso é todo um monólogo?}

Exatamente. Em "Darluz", também muito encenado por atrizes, lá, também temos uma típica ladainha nordestina:

Dei José, dei Antônio, Maria, dei. Daria. Dou. Quantos vierem. É só abrir o olho. Nem bem chorou, xô. Não posso criar. É feito gato,

\footnotetext{
${ }^{12}$ Compositor e cantor popular pernambucano (1911-1989).

${ }^{13}$ Trata-se do conto "A volta de Carmen Miranda”, publicado em BaléRalé.
} 
não tem mistério. É feito cachorro na rua, rato no esgoto. Moço, quem cria? É fácil pimenta no cu dos outros. Aí vem a madame, aí vem gente dizer: arranje um trabalho. Arranje você. Me dê o trabalho, agora. Não sei ler, não sei escrever, não sei fazer conta: José, Antônio, Maria, Isabel, Antônio. Dou nome assim só para não me perder. Quem mais? Evoé, Evandro. Agora chamem como quiser. O filho depois ganha vida importante. Sei de um que até é doutor sei-lá-de-quê, eu estou pouco me lixando. ${ }^{14}$

O ritmo parece que sempre é muito rápido. Tem algum conto com um ritmo mais lento ou não há?

Sim, aqui, por exemplo, no conto que fala da história do bailarino:

Ele, o bailarino, esteve em minha casa ontem e mais uma vez não quis dançar. Ai, por quê? Eu insisti, blablá. Tímido, ele ficou com as pernas amarelas e cruzadas, a posição do medo. Medo de quê, Nossa Senhora, de quê? Somos todos amigos. O sarau que realizamos prova isso. $\mathrm{O}$ povo à vontade, o povo sem maldade, $\mathrm{o}$ povo um povo só sensibilidade. ${ }^{15}$

Há as rimas, mas a serviço de uma história visivelmente mais longa. O tempo todo, ao escrever, eu não sei para onde o conto vai, mas ele tem que me convencer primeiramente como som, como música, disso ele tem que me convencer...

Falando agora sobre o conteúdo, a sua literatura não é considerada "literatura marginal ou periférica" como a do Ferréz, mas fala também de personagens marginalizados. Além disso, temos o Luiz Ruffato, que fala da violência no âmbito dos operários, e a Patrícia Melo, que fala da violência entre os mais privilegiados e a classe baixa. Qual seria, segundo você, a diferença entre a representação da violência nos seus contos e na literatura desses autores?

Eu não digo que escrevo sobre violência, eu digo que escrevo sob violência. Minha literatura conversa com a literatura de Ferréz, eu creio. Eu sou periférico. O nordestino é periférico. Eu carrego o Nordeste periférico comigo. Meus pais sertanejos, o bairro pobre onde eu morei no Recife, ter

\footnotetext{
${ }^{14}$ O conto "Darluz" também é parte do livro BaléRalé. Foi transformado numa curta-metragem por Leandro Goddinho (2009).

${ }^{15}$ Do livro BaléRalé.
} 
chegado em São Paulo desempregado, tendo indo morar na periferia de São Paulo, em um bairro chamado Jardim Aricanduva, depois em Guaianases, tudo isso me faz sentir muito irmão dessa literatura periférica que fazem Ferréz, Sérgio Vaz, Sacolinha, Binho, Allan da Rosa...

\section{E com relação a Luiz Ruffato e Patrícia Melo?}

Eu costumo brincar que a minha violência é muito sertaneja e muito centrada na figura do cangaceiro. Uma violência que se dá no grito, no aperreio, sem muito tempo para pensar. Nesse sentido, minha literatura difere-se da literatura de Patrícia Melo e de Ruffato. Outro ponto é a oralidade dos meus contos e dos meus personagens, que, como dito, é muito presente na cultura nordestina. E, repetindo, eu digo que escrevo sob violência e não sobre violência. Eu vivo num país no qual se abre o jornal e todo o tempo você tem informações sobre violência, sobre mortes, perseguições, sobre pessoas perdendo suas casas, e isso me afeta profundamente. Esse choque que sofri com a cidade de São Paulo está também no que eu escrevo. Difere-se evidentemente da literatura de Ruffato, que está um pouco mais ligada ao proletariado, ao operário, muito calcada na experiência dele como metalúrgico e centrada em personagens de Minas Gerais. E os contos dele são maiores, têm mais páginas, os meus são curtos em sua grande maioria, embora em "Eles eram muitos cavalos"16 haja uma série de histórias curtas, ali misturadas, conversando umas com as outras, em uma polifonia bem própria, bem urbana... Patrícia Melo, com sua experiência em romances, tem, digamos, uma outra "pegada" para retratar a realidade, é um grito mais contido, eu creio. Se é que há grito ali, digo, no que ela escreve, exagerado como os gritos que eu grito. Dizem que eu escrevo sobre pessoas malsucedidas; é que pessoas bem-sucedidas não me interessam. Eu também costumo dizer que escrevo para me vingar, nessa luta eterna entre oprimidos e opressores. Nesse sentido, repito, eu acredito que minha literatura se identifique mais com a de Ferréz. Embora hoje eu more em São Paulo e não more lá na periferia, eu tenho minhas raízes fincadas nesse lugar à margem - e essas raízes eu levo para a literatura.

${ }^{16}$ RUFFATO, Luiz (2001). Eles eram muitos cavalos. São Paulo: Boitempo. 
Em Contos negreiros se fala de racismo. Eu, entretanto, acho que ali o conceito de "negro" não se refere apenas a uma cor mas também a uma condição social. Qual é o conceito de "negro" nesse volume de contos?

Um pouco parecido com BaléRalé, esse livro é também sobre preconceitos e desigualdade social, sobre aparência, analfabetismo... Quando eu escrevi esse livro, minha intenção não era estudar de fora a situação do Brasil e apontar o que está errado, como quem diz: “Olhem o que estão fazendo com as crianças no Brasil, olhem o que estão fazendo com os negros no Brasil". Eu me coloco também como opressor nesse livro, eu também sou quem oprime. Desde a capa do livro, que contém a foto de um escravo brasileiro no século XIX, com um código de barras ocultando o órgão sexual dele, eu estou de alguma forma dizendo "Você, que está levando esse livro, vai ter que saber quanto é o livro e quanto é o negro que você está levando para casa". O meu receio de ter feito um livro como esse era de eu me colocar acima, como um branco querendo entender os problemas do Brasil e também que o livro viesse a se tornar um "discurso" de ONG. É por isso que eu me coloco também como opressor. Eu dedico esse livro, que é sobre negros, a Chocottone. Quem é Chocottone? Algum negro que tenho em casa? Algum escravo que mantenho em cativeiro? Ou meu namorado africano? Chocottone é um chocolate no Brasil e "chocolate" também é uma expressão que se usa para um negro. Muitos dos contos do livro tratam do turismo sexual, como no conto chamado "Meu negro de estimação", que é a história de um cara que melhorou a vida de um negro, o namorado dele... Eu gosto muito de me colocar na carne desses personagens e trabalhar com os chamados "deslocamentos". Com os avessos. Contra a massificação. Um dos meus personagens é contra a passeata homossexual, dizendo que, em sua época, havia mais poesia em ser homossexual do que hoje em dia. ${ }^{17}$ Outro conto é sobre uma mulher que é contra a paz, o conto "Da paz", do qual falei para vocês; ela não acredita nas passeatas pela paz... e depois, lendo o conto, é que você vai entender a "lógica", a dor do discurso dela. Ela perdeu um

\footnotetext{
${ }^{17}$ Em entrevista com Thiago Corrêa, Marcelino Freire explica, em relação ao conto "A volta de Carmem Miranda", que se inspirou no livro autobiográfico Antes que anochezca do escritor homossexual cubano Reinaldo Arenas (1943-1990): "Conto bastante baseado em frase que eu li do escritor cubano Reinaldo Arenas. Ele, sentindo saudades do tempo em que ele vivia sua homossexualidade em Cuba. Havia muito mais poesia ser homossexual em Cuba, dizia ele, mesmo tendo de lutar contra o regime". Disponível em: <http://www.vacatussa.com/entrevista-marcelinofreire/>. Acesso em: 9 jan. 2015.
} 
filho e diz: "Como é que eu posso ser a favor da paz se eu perdi meu filho em um ataque?". ${ }^{18}$ Então, eu apenas coloco essas questões e faço esses "deslocamentos" o tempo inteiro.

A violência que você retrata é a do Nordeste. Em que medida a sua literatura poderia ser considerada a continuação do Regionalismo do século $X X$, da literatura de autores como Graciliano Ramos, João Cabral, José Lins do Rego?

Acho que não. Estou longe disso. Eu acho que sou mais maracatu, mais repentista, mais cordel, mais cantoria, mais improviso... Sim, esses autores beberam nessa fonte popular. Eu bebi também nessa fonte. Por meio do ouvido. Mas eu sou também mais roqueiro, digamos. Sei lá... Claro que eu sou apaixonado por Graciliano Ramos, por João Cabral... Se existe algo que Graciliano, por exemplo, passou para os meus contos, me influenciou, foi com seu estilo telegráfico, preciso, com frases muito curtas. Eu aprendi a pontuar imitando Graciliano Ramos.

\section{Como em Vidas secas...}

Sim. Aquela pontuação, poucos adjetivos, poucos advérbios. Percebo também que meu trabalho conversa com o rap - se você colocar música, assim, musicar os meus textos, você terá um funk, um rap. Os meus contos põem o dedo na ferida. Como fazem algumas letras de rap. Fazemos parte de um só grito. Tudo está gritando em algum canto aqui, em meus livros. Meus personagens gritam, eles não se contêm porque está doendo alguma coisa e eles têm que gritar para entender essa dor. Um perdeu a mãe, outro perdeu o filho, está em briga com alguém, perdeu a dignidade, não tem o que comer. A região em que meus contos estão é essa região do grito. Agora mesmo eu escrevi o meu primeiro romance, que vai ser lançado em novembro 2013, chamado Nossos ossos ${ }^{19}$. Nele, eu precisei diluir esse grito, porque ficar gritando em 120 páginas seria demais; tentei encontrar um pouco mais a história, encontrar uma outra pegada, uma outra música... As rimas continuam lá, tanto as internas quanto as externas, começando pelo título, mas as sonoridades estão mais secas, digamos, estão mais silenciosas. Palavras contundentes,

\footnotetext{
${ }^{18}$ Fala do conto "Da paz", em Rasif: mar que arrebenta.

${ }^{19}$ FREIRE, Marcelino (2013). Nossos ossos. Rio de Janeiro: Record.
} 
como sempre, mas menos histéricas. Se, em meus contos, eu me aproximava de minha mãe, no meu romance eu me aproximei do silêncio de meu pai. $\mathrm{O}$ romance é dedicado a ele por causa disso. $\mathrm{O}$ silêncio dele era um silêncio poderoso. Era mortal, ao estilo dele, cortante... 